\title{
eudaimonia
}

Revija za pravnu, političku i

socijalnu teoriju i filozofiju

Br. $3 \cdot 2019$.

Izdavač

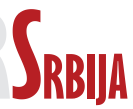

Srpsko udruženje za pravnu

i socijalnu filozofiju

MONETARY GOLD PRINCIPLE IN

JURISPRUDENCE OF THE INTERNATIONAL

COURT OF JUSTICE AND ITS APPLICATION

TO NUCLEAR DISARMAMENT

Matko Sanjin Jovanović

Strane: $71-86$ 

Matko Sanjin Jovanović $c^{*}$

\section{MONETARY GOLD PRINCIPLE IN JURISPRUDENCE OF THE INTERNATIONAL COURT OF JUSTICE AND ITS APPLICATION TO NUCLEAR DISARMAMENT}

This paper analyses the monetary gold principle in the jurisprudence of the International Court of Justice from its introduction in 1954 till the 2016 Marshall Islands cases. Since the responding states in the Marshall Islands cases put forward the monetary gold principle as their subsidiary argument, the paper aims to examine how the monetary gold principle is to be interpreted by the Court and concludes that the principle is not applicable in the cases concerning nuclear disarmament. In other words, should have the Court proceeded with the Marshall Islands' Application, it should have had rejected the monetary gold argument. The paper further acknowledges how the monetary gold principle stands in the way for the peaceful (judicial) settlement of disputes and the consequences arising therefrom.

Key words: Monetary Gold Principle. - Nuclear Disarmament. - Marshall Islands Cases. - International Court of Justice. - Jurisdictional objections.

\section{INTRODUCTION}

The monetary gold principle, introduced by the International Court of Justice in the Case concerning Monetary Gold Removed from Rome in 1942, raised new set of controversies in the most recent cases concerning the use of nuclear weapons in the Court's history - the Marshall Islands cases. The monetary gold principle relates to the [lack of] consent of one of the States whose interests are in a certain way affected by the potential Court's deliberation and will be explained in detail in the following paragraphs. The principle was shaped by the Court in altogether eight cases.

* Graduate student at the Faculty of Law, University of Zagreb; Member of the 2018 Jessup International Law Moot Court Competition, matkosanjin.jovanovic@ gmail.com. 
Sixty-two years after the ICJ introduced the principle in the case that mostly dealt with the aftermath of the Second World War, monetary gold principle found its way to the case concerning nuclear disarmament. In their application to the Court, Marshall Islands claimed that Article VI of the Treaty on the Non-Proliferation of Nuclear Weapons evolved into the norm of customary international law. Prima facie, Marshall Islands' application was thought of as a concern for all states that possess nuclear weapons, and not only the three Respondent states that were the parties to the proceedings in the most significant case concerning the use of nuclear weapons of the new century.

This paper will first deal with how the ICJ introduced and shaped the monetary gold principle through some of the cases in its significant jurisprudence. Secondly, the author will provide an overview of the Marshall Islands cases and matters concerning the nuclear disarmament. Thirdly, the author will put into perspective the monetary gold principle to the cases of nuclear disarmament in order to see whether the principle is applicable to these cases and what the consequences are of the [non] applicability of the principle.

\section{WHAT IS MONETARY GOLD PRINCIPLE?}

\subsection{Monetary Gold Removed From Rome in 1943}

Monetary gold principle was introduced by the International Court of Justice in 1954 in the case concerning the monetary gold that was seized by Germany from a bank in Rome during the Second World War. ${ }^{1}$ The gold belonged to the National Bank of Albania, but it has since been in possession of the three allied forces. In 1951, the Governments of the French Republic, the United Kingdom of Great Britain and Northern Ireland and the United States of America signed a Statement in Washington agreeing to deliver the gold to the United Kingdom, instead of to Albania, in partial satisfaction of the Judgment in the Corfu Channel case. ${ }^{2}$ However, in accordance with the aforementioned Washington Statement, Italy requested the monetary gold to be delivered to Italy, in partial satisfaction for the dam-

1 D.J., Harris, Cases and Materials on International Law, $5^{\text {th }}$ Edition, Sweet \& Maxwell, London 1998, 1029.

2 Case of the monetary gold removed from Rome in 1943 (Preliminary Question), Judgment of June $15^{\text {th }}, 1954,1954$ ICJ Reports 1954, [Monetary Gold case], 19. 
age caused to Italy by certain Albanian laws. ${ }^{3}$ This became the subject of the dispute before the Court, since the Washington Statement gave the Court jurisdiction in the matter - the question as to who is entitled to receive the gold. It was Albanian monetary gold that was requested by both Italy and the United Kingdom, while Albania refrained from making any application to the Court thereby not accepting its jurisdiction.

After the Republic of Italy instituted proceedings before the Court, few of the preliminary objections were raised, which are not of any greater significance to this paper's main proposition. As the Court noted, it "is not merely called upon to say whether the gold should be delivered to Italy or to the United Kingdom. It is requested to determine first certain legal questions upon the solution of which depends the delivery of the gold". ${ }^{4}$ The cornerstone of the dispute before the Court is the lack of Albania's consent for these proceedings instituted by Italy. Since Italy claimed that Albania had committed an internationally wrongful act by means of the Albanian law of January $13^{\text {th }}, 1945$, the Court was called upon to decide on the compliance of those laws with international law. In these questions, Italy and Albania are the only states that are directly interested and "to go into the merits of such questions would be to decide a dispute between Italy and Albania." ${ }^{5}$ Finally, the Court declined to exercise jurisdiction because of the lack of the consent of Albania and "to adjudicate upon the international responsibility of Albania without her consent would run counter to a well-established principle of international law embodied in the Court's Statute, namely, that the Court can only exercise jurisdiction over a State with its consent". ${ }^{6}$ Article 36 of the Statute of the International Court of Justice sets out that "the jurisdiction of the Court comprises all cases which the parties refer to it and all matters specially provided for in the Charter of the United Nations or in treaties and conventions in force". ${ }^{7}$ Since this requirement was not fulfilled in the dispute over the monetary gold, the Court lacks jurisdiction in the dispute. It is well established both in theory and practice that the jurisdiction of the

3 Ibid.

4 Ibid., 31.

5 Ibid., 32.

6 Ibid.

7 Charter of the United Nations, 26 June 1945, Can. T.S. 1945 No. 7, Statute of the International Court of Justice, Article 36. [Statute]. 
International Court of Justice (and its predecessor) is of a voluntary nature, that it cannot be presumed and that it must be strictly proved. ${ }^{8}$ In the Monetary Gold Case, the Court emphasized that "Albania's legal interests would not only be affected by the decision, but would form the very subject-matter of the decision". ${ }^{9}$

Judgment of 1954 that dealt with the monetary gold that was removed from Rome shaped what later became known as the monetary gold principle. It is worth mentioning here how Judge Crawford explained this principle most recently in 2016 by saying that "the Court lacks competence in a contentious case between State A and State B to determine that an extent third State, State C, is in breach of its legal obligations, [...] because State $\mathrm{C}$ has not consented to jurisdiction, State A's claim is inadmissible". ${ }^{10}$ This principle was examined in altogether eight cases before the International Court of Justice. Before this paper takes stance as to whether the principle is applicable or not to the Marshall Islands cases and nuclear disarmament, it is necessary to examine the jurisprudence of the Court related to the monetary gold principle after the 1954 judgment.

\subsection{Military and Paramilitary Activities in and against Nicaragua}

In the Case concerning Military and Paramilitary Activities in and against Nicaragua, Nicaragua instituted proceedings against the United States of America because of the alleged restrictions imposed to Nicaraguan ports and the laying of mines. ${ }^{11}$ In the preliminary phase of proceedings, while dealing with jurisdiction and admissibility of the application, the Court touched upon the monetary gold principle. The Court recited the case of Albania in the 1954 dispute, but further noted that "where however claims of a legal nature are made by an Applicant against a Respondent in proceedings before the Court, and made the subject of submissions, the Court has in principle merely to decide

8 H. Lauterpacht, International Law - Collected Papers, The general works, Cambridge University Press, Cambridge $2009^{1}, 24$.

9 Monetary Gold Case, supra, n. 3, 32.

10 Dissenting opinion of Judge Crawford, Obligations concerning Negotiations relating to Cessation of the Nuclear Arms Race and to Nuclear Disarmament (Marshall Islands v. India), Jurisdiction and Admissibility, Judgment, I.C.J. Reports 2016, 255.

11 International Court of Justice, https://www.icj-cij.org/en/case/70. 
upon those submissions, with binding force for the parties only, and no other State [...]". ${ }^{12}$ Furthermore, the Court emphasized that if other States consider that they may be affected are free to institute separate proceedings, or to employ the procedure of intervention, by means of Article 62 of the Statute of the Court. ${ }^{13}$ To conclude, if there are no legal questions with regard to other States that are not parties to the contentious case before the Court, there is no obstacle for the Court to exercise its jurisdiction (if other prerequisites are fulfilled).

\subsection{Land, Island and Maritime Frontier Dispute}

In the case between El Salvador and Honduras (with Nicaragua intervening), the Parties requested the Court, by means of a Special Agreement ${ }^{14}$, to delimit the frontier line in the six sectors that were previously not delimited by the 1980 General Treaty of Peace and to determine the legal situation of the islands in the Gulf of Fonseca and the maritime spaces within and outside it. ${ }^{15}$ It was Nicaragua in the Land, Island and Maritime Frontier Dispute, who recalled the Monetary Gold case stating that "its interests are so much part of the subject-matter of the case that the Chamber could not properly exercise its jurisdiction without the participation of Nicaragua". 16 The Court, however, made a clear difference between the position of Nicaragua in the dispute over certain issues in the Gulf of Fonseca and the position of Albania in the Monetary Gold case. In the latter, it was the international responsibility that had to be determined in order to deliver the judgment on the merits. In other words, the very subject-matter of the judgment on the merits would impose international responsibility on a State that was not a party to proceedings, neither in the form of a party nor an intervener.

12 Military and Paramilitary Activities in and against Nicaragua (Nicaragua v. United States of America), Jurisdiction and Admissibility, Judgment, ICJ Reports 1984, 392.

13 Ibid.; Statute, supra n. 8, Article 62.

14 Special Agreement concluded at Esquipulas (Guatemala) on 24 May 1986 between the Republic of El Salvador and the Republic of Honduras for the submission to the decision of the International Court of Justice of a dispute between the two states, jointly notified to the Court on 11 December 1986, 1986 General List: No. 75.

15 International Court of Justice, https://www.icj-cij.org/en/case/75.

16 Land, Island and Maritime Frontier Dispute (El Salvador/Honduras), Judgment of 11 September 1992, I.C.J. Reports 1992, para. 52. 


\subsection{Certain Phosphate Lands in Nauru}

In 1989, the Republic of Nauru instituted proceedings against the Commonwealth of Australia with regard to the dispute concerning the rehabilitation of certain phosphate lands that were mined before Nauruan independence. According to the 1947 Trusteeship Agreement for Nauru, Nauruan administering authority consisted of Australia, New Zealand and the United Kingdom. Nauru claimed that Australia breached international law embodied in the Trusteeship Agreement, the Charter of the United Nations and certain norms of general international law. However, before the case went into the merits, Australia raised certain preliminary objections that were then dealt within the Judgment of 1992. This Judgment is of great importance with regard to how the Court reinterpreted the monetary gold principle and gave further explanation of the 1954 concept.

Firstly, Australia contended that "any decision of the Court as to the alleged breach by Australia of its obligations under the Trusteeship Agreement would necessarily involve a finding as to the discharge by those two other States of their obligations in that respect, which would be contrary to the fundamental principle that the jurisdiction of the Court derives solely from the consent of States". ${ }^{17}$ After the Court recalled the Monetary Gold case, it went on to say that "the determination of the responsibility of New Zealand or the United Kingdom is not a prerequisite for the determination of the responsibility of Australia, the only object of Nauru's claim" 18 , thereby making a difference of this case to the position of Albania in the Monetary Gold case. The cornerstone of the Nauru/Australia case is, however, contained in the Court's assertion that "a finding by the Court regarding the existence or the content of the responsibility attributed to Australia by Nauru might well have implications for the legal situation of the two other States concerned, but no finding in respect of that legal situation will be needed as a basis for the Court's decision on Nauru's claims against Australia". ${ }^{19}$ This proposition is of great importance to the present issue with respect to the nuclear disarmament cases. What Court basically said in the 1992 Judgment meant that the decision of the Court in one case may have implications for the legal situation of other states,

17 Certain Phosphate Lands in Nauru (Nauru v. Australia), Preliminary Objections, Judgment, I.C.J. Reports 1992, 240, para. 49.

18 Ibid. para. 55.

19 Ibid. 
but their lack of participation in the case before the Court does not mean that the Court should decline to exercise its jurisdiction. If we put the Phosphate Lands case into perspective of nuclear disarmament, we can rely on the proposition suggested by Judge Shahabuddeen in the Phosphate Lands case: "That others had the same obligation does not lessen the fact that Australia had the obligation. It is only with Australia's obligation that the Court is concerned. In contrast with the situation in the Monetary Gold case, the decision of the Court as between Nauru and Australia will not be based on the obligation of New Zealand and the United Kingdom". ${ }^{20}$

\subsection{Case concerning East Timor}

In 1991, Portugal instituted proceedings against Australia concerning certain activities of Australia with respect to East Timor, in connection with a treaty between Australia and Indonesia which created a Zone of Cooperation in a maritime area between the Indonesian Province of East Timor and Northern Australia. ${ }^{21}$ Early in the proceedings, Australia raised the monetary gold objection asserting that "the Monetary Gold case is directly applicable to the case now brought by Portugal, because the Court cannot decide this case without deciding a) the international responsibility of Indonesia for any wrongdoing in relation to the people of East Timor, b) the resulting rights and obligations of Indonesia in respect of the territory of East Timor, and c) the entitlement of Indonesia in 1989 to negotiate and conclude the Timor Gap Treaty". ${ }^{22}$ Australia further noticed that the claim contravenes the principle of consent which bars adjudication of the legal responsibility of Indonesia without its agreement since the whole allegation depends upon the legality of Indonesias claim to represent the people of the territory. ${ }^{23}$ According to $X X X$, "the East Timor case is the second, and so far the last case, in which the ICJ has accepted the jurisdictional objection which was based on the Monetary Gold principle". 24 The East Timor case, together with the Phosphate Lands case will serve as cru-

20 Separate Opinion of Judge Shahabuddeen to the Judgment of the Court of 26 June 1992, Certain Phosphate Lands in Nauru, supra n. 18, 296-297.

21 International Court of Justice, https://www.icj-cij.org/en/case/84.

22 Counter-Memorial of the Government of Australia, East Timor (Portugal v. Australia), 1 June 1992, International Court of Justice, para. 194.

23 Ibid.

24 N. Zamir, "The applicability of the Monetary Gold principle in international arbitration", Arbitration International, 33/2017, 526. 
cial example in the Marshall Islands cases that will be discussed further in this paper.

\subsection{Monetary gold principle concluded}

The monetary gold principle, as introduced by the ICJ as early as in 1954, was shaped through many cases in the Court's jurisprudence. ${ }^{25}$ After its introduction, many States parties put the principle forward in their written and oral arguments before the ICJ, usually trying to evade the Court's jurisdiction. It is important to notice that interpretation of the monetary gold principle varies from one case to another and that one cannot merely say that the principle should be read restrictively or extensively. As Judge Crawford contends, "the monetary gold ground of inadmissibility is particularly sensitive to the precise basis of the Applicant's claim. The decision of a given case may or may not rest on a prior determination of the legal position of a third State depending on how the case is put". ${ }^{26}$ Furthermore, Judge Crawford emphasizes that interpretation and application of the monetary gold principle is an issue for the merits, pointing further that the resolution of the dilemma rests upon the facts of each and every case individually. However, it can generally be contended that "the ICJ elaborated that it will not exercise jurisdiction where the legal interests of a third state would not only be affected by a decision, but would form the very subject-matter of the decision" ${ }^{27}$ In the most recent cases with respect to negotiations relating to cessation of the nuclear arms race and to nuclear disarmament, the three respondent States in three respective cases raised the monetary gold principle as a subordinate argument with the purpose of evading the Court's jurisdiction. According to the previously said, it is important to clarify the contents of the Marshall Islands cases in order to see whether the monetary gold principle may be justified as a valid argument or not, or in other words, whether legal interests of third states are not only affected by the [potential] decision or those would also form the very subject-matter of the decision.

25 Apart from the ones examined so far, the monetary gold principle was further discussed in Application of the Convention on the Prevention and Punishment of the Crime of Genocide (Croatia v. Serbia), Judgment, I. C. J. Reports 2015 (I), 57-58, para. 116. The Court's reasoning in this case had no greater impact on the general proposition of the monetary gold principle shaped so far by the same Court.

26 Dissenting opinion of Judge Crawford, supra n. 11, 526.

27 Zamir, supra 25, 524.; Monetary gold case, supra n. 3, 32. 


\section{MARSHALL ISLANDS CASES}

\subsection{Background of the Application to the ICJ and Article VI of the Non-Proliferation Treaty}

The best overview of what happened in April 2014 in the Hague can be put into the following quotation: "On 24 April 2014, the Marshall Islands filled a number of Applications, including one against India. It accuses the latter of not fulfilling its obligations relating to the cessation of the nuclear arms race at an early date and to nuclear disarmament". 28 To understand why Marshall Islands decided to commence proceedings against various Respondents, it is important to notice that the Marshall Islands, together with Kazakhstan, "are the two most irradiated nations on earth as a result of nuclear weapons tests by the two superpowers during the Cold War". ${ }^{29}$ The reason being the fact that Marshall Islands became a testing site from 1946 to 1958 with 67 nuclear weapons of varying explosive power being detonated on different locations, regardless of their closeness to people. ${ }^{30}$ Some reports suggest that the residents of the Marshall Islands "experienced from 1946 to 1958 unprecedented fallout and environmental contamination that compromised the health of the individuals, communities, and an entire nation". 31 The move to sue nuclear superpowers sparked enormous fire among politicians, academics, international lawyers, media etc. All in all, Marshall Islands instituted proceedings against nine nuclear weapon states - China, North Korea, France, India, Israel, Pakistan, Russia, the United Kingdom, and the United States of America. For the purposes of depicting the current state of international law with respect to nuclear weapons, the case between Marshall Islands and India will serve as a model-case.

28 International Court of Justice, https://www.icj-cij.org/en/case/158.

29 http://www.abolition2000.org/en/news/2016/09/06/marshall-islandsspeaker-urges-disarmament-during-visit-to-kazakhstan-test-site/.

30 Report of the Special Rapporteur on the implications for human rights of the environmentally sound management and disposal of hazardous substances and wastes, Calin Georgescu; Addendum, Mission to the Marshall Islands and the United States of America, 3 September 2012, dic. A/HRC/21/48/Add.1.

31 Submission to the United Nations Universal Periodic Review of the Republic of the Marshall Islands - "Environment, health, and other human rights concerns associated with nuclear weapons testing, fallout, involuntary displacement, human subject experimentation, and the failure to achieve durable solutions that protect the environment and safeguard the rights of the people of the Marshall Islands", Center for Political Ecology, 15 September 2014, para. 5. 
Marshall Islands started their Application instituting proceedings against India by mentioning the cornerstone propositions set out in the Court's Advisory Opinion of 8 July 1996 on the Legality of the Threat or Use of Nuclear Weapons. ${ }^{32}$ However, the Application should not be seen as "an attempt to re-open the question of the legality of nuclear weapons" ${ }^{33}$ On the other hand, the case dealt with Article VI of the Treaty on the Non-Proliferation of Nuclear Weapons (hereinafter: the NPT) and its alleged customary character. ${ }^{34}$

Article VI of the NPT states that "each of the Parties to the Treaty undertakes to pursue negotiations in good faith on effective measures relating to cessation of the nuclear arms race at an early date and to nuclear disarmament, and on a treaty on general and complete disarmament under strict and effective international control". ${ }^{55}$ With regard to the ICJ's Advisory Opinion of 8 July 1996, it is important to notice that the Advisory Opinion confirms the NPT's Article VI since "there exists an obligation to pursue in good faith and bring to a conclusion negotiations leading to nuclear disarmament in all its aspects under strict and effective international control". ${ }^{36}$

Evidence as to the customary character of Article VI is set out in the remainder of the Marshall Islands' Application. Since providing evidence for the customary character of the aforementioned norms overcomes the scope of this paper, those questions will not be examined. The emphasis of the forthcoming paragraphs will be put on the similarities of the Marshall Islands cases with the aforementioned cases in which monetary gold was interpreted and considered before the International Court of Justice. After all, it was the Court that was supposed to answer the question whether Article VI of the NPT evolved into the norm of customary international law and whether it thereby bounds all states of the international community. This paper only aims to prove that monetary gold principle does not stand in the way of reaching that answer.

32 Obligations concerning Negotiations Relating to Cessation of the Nuclear Arms Race and to Nuclear Disarmament (Marshall Islands v. India), Application Instituting Proceedings, 2014 General List No. 158, 6.

33 Ibid.

34 Ibid.

35 Treaty on the Non-Proliferation of Nuclear Weapons, 5 March 1970, 729 UNTS 161.

36 Legality of the Threat or Use of Nuclear Weapons, Advisory Opinion, I.C.J. Reports 1996 (I), 226, para. 105. 


\subsection{Monetary principle as subsidiary argument/preliminary objection posed by the responding states}

Even though Marshall Islands sued all nine nuclear weapons states, only three states ended up defending themselves at the ICJ since they were the only ones that deposited declarations of acceptance of the Court's jurisdiction in accordance with Article 36 paragraph 2 of the Statute of the ICJ. Namely, those states are India, Pakistan and the United Kingdom. All these states defended themselves in a comprehensive way by means of different preliminary objections before going into the merits of the case. It is not a spoiler if we mention here that the ICJ ruled "in favour" of the three responding states by stating that there is no dispute between them on one side and Marshall Islands on the other. The subsidiary argument put forward by all three States was based on the monetary gold principle introduced sixty-two years earlier in the 1954 Judgment in the Case concerning Monetary Gold Removed from Rome in 1943.

India asserted that "a sensible resolution and effective relief of the problem sought to be remediated in the Application would only be if the obligation were to be performed jointly by all of them with the active participation of non-nuclear weapon States, including States that rely on the nuclear umbrella provided by nuclear weapon States". 37 Furthermore, India asserted that "the effective resolution of the question of nuclear disarmament must necessarily be the subject matter of a multilateral treaty" and that "all States are indispensable Parties, since all would be affected by the Judgment of the Court sought by the Republic of Marshall Islands". ${ }^{38}$ Finally, India warned that such action would result in the International Court of Justice attainment of the international legislative function which goes beyond its jurisdiction and is strictly preserved for the other UN (primarily inter-governmental) forums. ${ }^{39}$ India, of course, recalled the monetary gold principle and certain case law where the principle was interpreted.

37 Obligations concerning Negotiations Relating to Cessation of the Nuclear Arms Race and to Nuclear Disarmament (Marshall Islands v. India), Counter-Memorial of the Republic of India, 16 September 2015, para. 34.

38 Ibid. para. 42.

39 Ibid. 
In proceedings against the United Kingdom, the respondent made clear in their Preliminary Objections that "as a matter of simple logic, the United Kingdom cannot conduct, still less conclude, nuclear disarmament negotiations on its own" ${ }^{40}$ The UK continues and asserts that "the Court cannot (...) rule on the conduct of the United Kingdom without concurrently necessarily and inevitably evaluating the lawfulness of the conduct of other States" and that other State's interests form the very subject matter of the decision. ${ }^{41}$ The UK concludes that the filling of materially identical applications by Marshall Islands against all the nine nuclear weapon states suggests that the claim in question is based "on the relationship between the United Kingdom and the other nuclear-weapon States collectively" and that "the legal interests of those other 8 States consequently form the very subject matter of the Marshall Islands' claim against the United Kingdom". ${ }^{2}$ As was the case with India, the UK relied on the monetary gold principle.

Finally, in the third proceeding, Pakistan contended that "the Court cannot decide whether the obligations set out in Article VI of the NPT and/or alleged customary international law obligations rooted and enshrined in Article VI of the NPT have been violated, with consequences for third parties, unless other affected third States are a party to these proceedings". ${ }^{43}$ More clearly, Pakistan contends that "a finding of the NPT parties' legal obligations under Article VI of the NPT and/or customary international law obligations as alleged by the RMI in its Application is a precondition for determining the RMI's claims against Pakistan". ${ }^{44}$ What reminds us of the Case concerning the Military and Paramilitary Activities in and against Nicaragua, Pakistan states that "the participation of those third States is required for the full development of the facts to determine the rights and obligations of the Parties now before the Court" and that "it is very likely that facts which are relevant to the Application may not be in the possession or control of the Parties before the Court" ${ }^{45}$ Once again, Pakistan relied on the monetary gold principle.

40 Preliminary Objections of the United Kingdom of Great Britain and Northern Ireland (Marshall Islands v. United Kingdom), 15 June 2015, para. 84.

41 Ibid.

42 Ibid. para. 93.

43 Counter-Memorial of Pakistan (Marshall Islands v Pakistan) (Jurisdiction and admissibility), 1 December 2015, para. 8.75.

44 Ibid. para. 8.80.

45 Ibid. para. 8.86. 
It has to be noted that all the three Responding States relied on the monetary gold principle as a subsidiary argument. The first argument of all three states was that there existed no dispute between the Applicant and them. The Court accepted that argument and never truly proceeded to the monetary gold argument. One notice of the monetary gold can be tracked in the Dissenting opinion of Judge Crawford in the case with India where He nominated it as "perhaps the most plausible of the other objections to jurisdiction and admissibility made by the Respondent". ${ }^{46}$ However, Crawford admitted that "a third State could breach an obligation to negotiate by its own conduct and the Court could determine as much" which all depends on the scope of Article VI of the NPT (or any parallel customary international law that entails Article VI) ${ }^{47}$ However, "these are all issues for the merits". ${ }^{48}$

\section{4. [NON]APPLICABILITY OF THE MONETARY GOLD PRINCIPLE TO THE MARSHALL ISLANDS CASES}

As it was mentioned above, the Court ruled that there is no dispute in the cases between the Responding States on one side, and the Marshall Islands on the other. However, it is necessary to see whether the Responding States would evade the Court's jurisdiction by means of their subordinate argument, the monetary gold principle.

Should we take the case between Marshall Islands and India, we need to determine whether the breach of Article VI of the NPT or the corresponding norm of customary international law embodied in Article VI of the NPT by any other nuclear State that is not a party to the proceedings, for instance, the United States of America, forms the very subject-matter of the dispute between Marshall Islands and India. According to the author of this paper, this is not the case. If we put this case into perspective with Certain Phosphate Lands in Nauru, the determination of the responsibility of the United States of America or of any other nuclear State is not a prerequisite for the determination of the responsibility of India. ${ }^{49}$ In the dispute between Marshall Islands and India, only the responsibility of India is to be determined (or not)

\footnotetext{
46 Dissenting opinion of Judge Crawford, supra n. 11, para. 29.

47 Ibid. para. 30.

48 Ibid.

49 See Certain Phosphate Lands in Nauru, supra n. 18.
} 
and the responsibility of any other nuclear State does not come into question. Certainly, there might come to light certain implications to the legal situation of other States not parties to the dispute before the Court, but such is recognized as not to form a bar to the ICJ's adjudication. To what extent would those implications interfere with other States interests and privileges enshrined in the Charter of the United Nations is however unknown. To continue, the ICJ does not have to determine that any other State, which is not a party to the proceedings, is in breach of Article VI of the NPT or the corresponding norm of customary international law to determine that only one of them, in this case India, that is a party to the proceedings, is in breach of that same norm. Furthermore, the interests of other states that stand outside the Marshall Islands/India case are well protected by nature of Article 59 of the Statute of the Court since "the decision of the Court has no binding force except between the parties and in respect of that particular case." ${ }^{50}$ It is uncertain to what extent Marshall Islands would achieve their goal, the denuclearization of the planet, with Article 59 standing in their way, but that question most certainly overcomes the scope of this paper. What Marshall Islands probably aimed at, as Judge Crawford put it, "it is true, for example, that the Court cannot order third States to enter into negotiations, and that one cannot negotiate alone. But a third State could breach an obligation to negotiate by its own conduct and the Court could determine as much." 51 What is relevant is that the Court needs to deal with India's breach of Article VI of the NPT or the corresponding norm of customary international law only and no other State's breach of those norms come into the heart of the Marshall Islands/India dispute.

Furthermore, there are few more (less compelling but nevertheless) arguments in favour of the non-applicability of the monetary gold principle in any of the Marshall Islands cases, one of them being put forward by Judge Weeramantry in His Dissenting opinion of 1995 (East Timor). Judge Weeramantry points out quite the opposite to the monetary gold principle - the judicial duty to decide the cases brought before the Court within its jurisdictional competence. ${ }^{52}$ And while "there will in many cases be an area of doubt, in which the case

50 Statute, supra n. 8, Article 59.

51 Dissenting opinion of Judge Crawford, s. note 11, 526.

52 Dissenting opinion of Judge Weeramantry, Legality of the Threat or Use of Nuclear Weapons, supra n. 37, 156 
could well fall within the operation of one principle or the other", 53 opinion of the author of this paper is that the monetary gold principle should rather be interpreted restrictively instead of extensively, giving the Court the opportunity to decide the case rather than to allow the States to effectively evade a peaceful settlement of disputes for which the Court was (re-)established in the first place.

Another argument in favour of the Marshall Islands was put forward back in 1986 by Sir Gerald Fitzmaurice, who contested that "since the national law will normally ensure that there is some domestic forum competent to hear and determine all cases involving breaches of that law (...) a claimant who fails on jurisdictional grounds in one forum can start again in the correct one. Thus, as a general rule, there is no avoiding a determination on the merits if the claimant persists, and the defendant obtains no ultimate advantage by raising jurisdictional issues. It is far otherwise in the international field where a jurisdictional objection, if successful, will normally dispose of the case entirely, and rule out any further proceedings, not only before the tribunal rendering the jurisdictional decision, but before any other" ${ }^{54}$ Fitzmaurice concludes that jurisdictional issues and complications arising therefrom are usually of far greater and fundamental importance. ${ }^{55}$ In this manner, Judge Weeramantry points out the differences between international and a domestic legal system, vouching in favour of a restrictive approach to the monetary gold principle in international judiciary. ${ }^{56}$

Last, but not least, the international (legal) system shaped oftentimes by the institutions of the United Nations aims in the direction of a nuclear-free world. Antonio Guetteres, the Secretary General of the United Nations, states the following: "The only sure way to eliminate the threat posed by nuclear weapons is to eliminate the weapons themselves." ${ }^{57}$ Perhaps it is not convenient to cite such statements when trying to find a legal way-out from the monetary gold (miss-)conception, but a scholar might also conclude the following: if the monetary gold principle stands in the way of the denuclearization, one should rule in favour of the non-applicability of it before the In-

53 Ibid.

54 G. Fitzmaurice, The Law and Procedure of the International Court of Justice, Cambridge University Press, Cambridge 1986, 438.

55 Ibid.

56 Dissenting opinion of Judge Weeramantry, supra n. 53.

57 Secretary-General's Message, Antonio Guterres, published at: http://www. un.org/en/events/nuclearweaponelimination/message.shtml. 
ternational Court of Justice, the guardian of our common international (legal) order. After all, the Secretary General pledged His own personal support and that of the United Nations system "in any and every way", toward the world free of nuclear weapons.

\section{REFERENCES}

Harris D.J., Cases and Materials on International Law, $5^{\text {th }}$ Edition, Sweet \& Maxwell, London, 1998

Charter of the United Nations, 26 June 1945, Can. T.S. 1945 No. 7, Statute of the International Court of Justice

Lauterpacht H., International Law - Collected Papers, Volume 1, The general works, Cambridge University Press, Cambridge

Zamir N., The applicability of the Monetary Gold principle in international arbitration, Arbitration International, vol. 33, 2017

Report of the Special Rapporteur on the implications for human rights of the environmentally sound management and disposal of hazardous substances and wastes, Calin Georgescu; Addendum, Mission to the Marshall Islands and the United States of America, 3 September 2012, dic. A/ HRC/21/48/Add.1

Submission to the United Nations Universal Periodic Review of the Republic of the Marshall Islands - Environment, health, and other human rights concerns associated with nuclear weapons testing, fallout, involuntary displacement, human subject experimentation, and the failure to achieve durable solutions that protect the environment and safeguard the rights of the people of the Marshall Islands, Center for Political Ecology, 15 September 2014

Treaty on the Non-Proliferation of Nuclear Weapons, 5 March 1970, 729 UNTS 161

Fitzmaurice G., The Law and Procedure of the International Court of Justice, Vol. II, 1986 